\title{
Chemosymbiotic species from the Gulf of Cadiz (NE Atlantic): distribution, life styles and nutritional patterns
}

\author{
C. F. Rodrigues, A. Hilário, and M. R. Cunha \\ Departamento de Biologia \& CESAM - Universidade de Aveiro, Aveiro, Portugal \\ Correspondence to: C. F. Rodrigues (clara.rodrigues@ua.pt) \\ Received: 28 November 2012 - Published in Biogeosciences Discuss.: 7 December 2012 \\ Revised: 7 March 2013 - Accepted: 25 March 2013 - Published: 17 April 2013
}

\begin{abstract}
Previous work in the mud volcanoes from the Gulf of Cadiz (South Iberian Margin) revealed a high number of chemosymbiotic species, namely bivalves and siboglinid polychaetes. In this study we give an overview of the distribution and life styles of these species in the Gulf of Cadiz, determine the role of autotrophic symbionts in the nutrition of selected species using stable isotope analyses $\left(\delta^{13} \mathrm{C}, \delta^{15} \mathrm{~N}\right.$ and $\delta^{34} \mathrm{~S}$ ) and investigate the intra-specific variation of isotope signatures within and between study sites. During our studies, we identified twenty siboglinidae and nine bivalve chemosymbiotic species living in fifteen mud volcanoes. Solemyid bivalves and tubeworms of the genus Siboglinum are widespread in the study area, whereas other species were found in a single mud volcano (e.g. "Bathymodiolus" mauritanicus) or restricted to deeper mud volcanoes (e.g. Polybrachia sp., Lamelisabella denticulata). Species distribution suggests that different species may adjust their position within the sediment according to their particular needs, and to the intensity and variability of the chemical substrata supply. Tissue stable isotope signatures for selected species are in accordance with values found in other studies, with thiotrophy as the dominant nutritional pathway, and with methanotrophy and mixotrophy emerging as secondary strategies. The heterogeneity in terms of nutrient sources (expressed in the high variance of nitrogen and sulphur values) and the ability to exploit different resources by the different species may explain the high diversity of chemosymbiotic species found in the Gulf of Cadiz. This study increases the knowledge on distributional patterns and resource partitioning of chemosymbiotic species and highlights how trophic fuelling varies on spatial scales with direct implications to seep assemblages and potentially to the biodiversity of continental margin.
\end{abstract}

\section{Introduction}

The finding that hydrothermal vent mussels have a significantly depleted $\delta^{13} \mathrm{C}$ signature, very distinct from the values of other typical deep-sea invertebrates, led Rau and Hedges (1979) to postulate that these mussels rely on some nonphotosynthetic food source. Later this finding was repeated for several cold seep invertebrates, and confirmed by the observation that they host symbiotic chemoautotrophic bacteria (Conway et al., 1994; Cavanaugh et al., 1992). In this symbiotic relationship, the invertebrate host facilitates the access to inorganic carbon, oxygen and reduced sulphur-compounds, and in return it uptakes the bacterial metabolic byproducts or digests symbiont tissue for its nutrition (Fisher, 1990; MacAvoy et al., 2002). The carbon source for thiotrophic and methanotrophic bacteria is different, with the former using pore water or near-bottom water dissolved inorganic carbon (DIC) and the latter using $\mathrm{CH}_{4}$ (Fisher, 1990; Conway et al., 1994).

The different carbon fixation pathways involve distinct isotopic fractionation (e.g. carbon, sulphur and nitrogen), which makes stable isotope approaches particularly useful for elucidating the nutritional status of organisms in vent and seep environments (Conway et al., 1994; Van Dover and Fry, 1994). Carbon isotopic values have been used to differentiate animals with thiotrophic symbionts from those with methanotrophic symbionts (Brooks et al., 1987; Kennicutt et al., 1992), and to identify the source methane pool as either thermogenic or biogenic (Sassen et al., 1999). Chemoautotrophs tend to have lower $\delta^{15} \mathrm{~N}$ values than heterotrophs or marine phytoplankton, and the $\delta^{34} \mathrm{~S}$ values of animals hosting thiotrophic bacteria are depleted relative to animals with methanotrophic symbionts and to heterotrophs 
(Brooks et al., 1987). In fact, values of $\delta^{34} \mathrm{~S}$ below $5 \%$ can be used to infer a thiotrophic mode of nutrition (Vetter and Fry, 1998) reflecting the isotopic signature of the sulphide source (Fisher, 1995). Stable isotope signatures can therefore provide information on food resource use and partitioning, both inter- and intraspecifically (Levesque et al., 2003).

Previous work in the Gulf of Cadiz mud volcanoes (South Iberian Margin) found a high number of chemosymbiotic species, namely bivalves and siboglinid polychaetes (Rodrigues et al., 2008; Hilário and Cunha, 2008; Hilário et al., 2010; Oliver et al., 2011), and studies on the faunal assemblages in the area show high biodiversity and high variability in structure, composition and density, which are likely to result from a combination of biogeographic, historical and environmental factors (Cunha et al., 2013). Especially relevant for the distribution of chemosymbiotic species is the variability in the fluid sources and transport mechanisms determining the intensity of the fluxes and the geochemistry of the porewater and sediments.

The Gulf of Cadiz is an extensive cold seepage area including over 40 mud volcanoes at depths between 200 and $4000 \mathrm{~m}$ (Pinheiro et al., 2003; Van Rensbergen et al., 2005). The molecular and isotopic composition of the hydrocarbon gases present in the different mud volcanoes reveal a predominance of thermogenic sources with varying degrees of thermal maturity (Mazurenko et al., 2002, 2003; Stadnitskaia et al., 2006; Hensen et al., 2007; Nuzzo et al. 2008) and, in some cases, partial recycling of thermogenic methane and other hydrocarbons mediated by anaerobic oxidation of methane (AOM)-related methanogenic archaea in the shallow sediments (Nuzzo et al., 2009). Differences in both fluid geochemistry and composition of the microbial assemblages responsible for the AOM activity have a major influence on the quantity and chemical composition of the hydrocarbons reaching near-surface sediments or the water column and offer a multitude of physicochemical niches that can be exploited by species with different anatomical features, physiology and symbiotic associations.

Symbiotic bivalves in the Gulf of Cadiz include members of five of the six families known to host chemoautothrophic bacteria: Solemyidae, Lucinidae, Thyasiridae, Vesicomyidae, and Mytilidae (Génio et al., 2008; Rodrigues et al., 2008; Oliver et al., 2011). These bivalves have different anatomical organization, particularly in relation to the structure of the gill that in all of them are modified to house the symbionts (reviewed by Taylor and Glover, 2010). They also have very different life styles ranging from deep sediment burrowers to epibenthic byssus-tethered species. Bathymodiolin mussels (family Mytilidae) further differ from the other chemosymbiotic bivalves in the way that they have retained their filter feeding ability and are capable of cohosting sulphur- and methane-oxidising symbionts; the former are also able to utilise hydrogen as energy source (Fisher et al., 1993; Duperron et al., 2008; Petersen et al., 2011).
Siboglinid polychaetes are represented in the Gulf of Cadiz by a high diversity of frenulates (Hilário et al., 2010). Frenulata, the most specious clade of siboglinids, include a wide range of body sizes and tube morphologies. They live in a variety of reducing environments, including shelf and slope sediments, cold seeps, hydrothermal vents and organic falls, with their tube spanning oxic-anoxic boundaries (Hilário et al., 2011). The anterior end of the tube remains at the sediment surface or extends into the oxygenated bottom water, where oxygen is absorbed by a gill-like structure. Hydrogen sulphide, or methane in the case of Siboglinum poseidoni that harbours methane-oxidising endosymbionts (Schmaljohann and Flügel, 1987), is transported across the posterior tube and body wall into the trophosome, a specialized tissue where the endosymbiotic bacteria are housed (reviewed by Hilário et al., 2011). In addition to the nutrition provided by their symbionts, species of the genus Siboglinum can take up and metabolise dissolved organic compounds at a rate sufficient to sustain respiration but not enough for growth and reproduction (Southward and Southward, 1981).

Due to its characteristics (biogeographical location, large number of seeps, seep regime variability), the Gulf of Cadiz provides a unique setting for the study of chemosynthesisbased assemblages. The high diversity of chemosymbiotic species found in the Gulf of Cadiz led us to hypothesize that (1) at small spatial scales different morphological and life style adaptations allow the co-occurrence of species and trophic niche partitioning, and (2) trophic diversity under differential geochemical conditions results in high biodiversity at local and regional scales. Herein, we determine the trophic range of chemosymbiotic species using stable isotope analyses $\left(\delta^{13} \mathrm{C}, \delta^{15} \mathrm{~N}\right.$ and $\left.\delta^{34} \mathrm{~S}\right)$ and analyse the results in relation to their distributions at different spatial scales. Furthermore, we assess intra and interspecific differences in the trophic range of chemosymbiotic species occurring at the same and at different sites and discuss them in the light of sediment geochemistry.

\section{Material and methods}

Chemosymbiotic species were obtained from macrofaunal samples collected during 14 cruises carried out between 2000 and 2009 from numerous locations in the Gulf of Cadiz using a variety of quantitative and non-quantitative sampling devices and processed on board as described by Rodrigues et al. (2011a). Chemosymbiotic bivalves and siboglinid tubeworms were sorted and identified; Siboglinum and Polybrachia specimens were ascribed to species according to Hilário et al. (2010) or given new codenames consistent throughout the samples when they did not yet match a known species. Specimens from the largest and more abundant species (five bivalve and seven tubeworm species) were dissected on board and the tissues (e.g. gill and foot for 


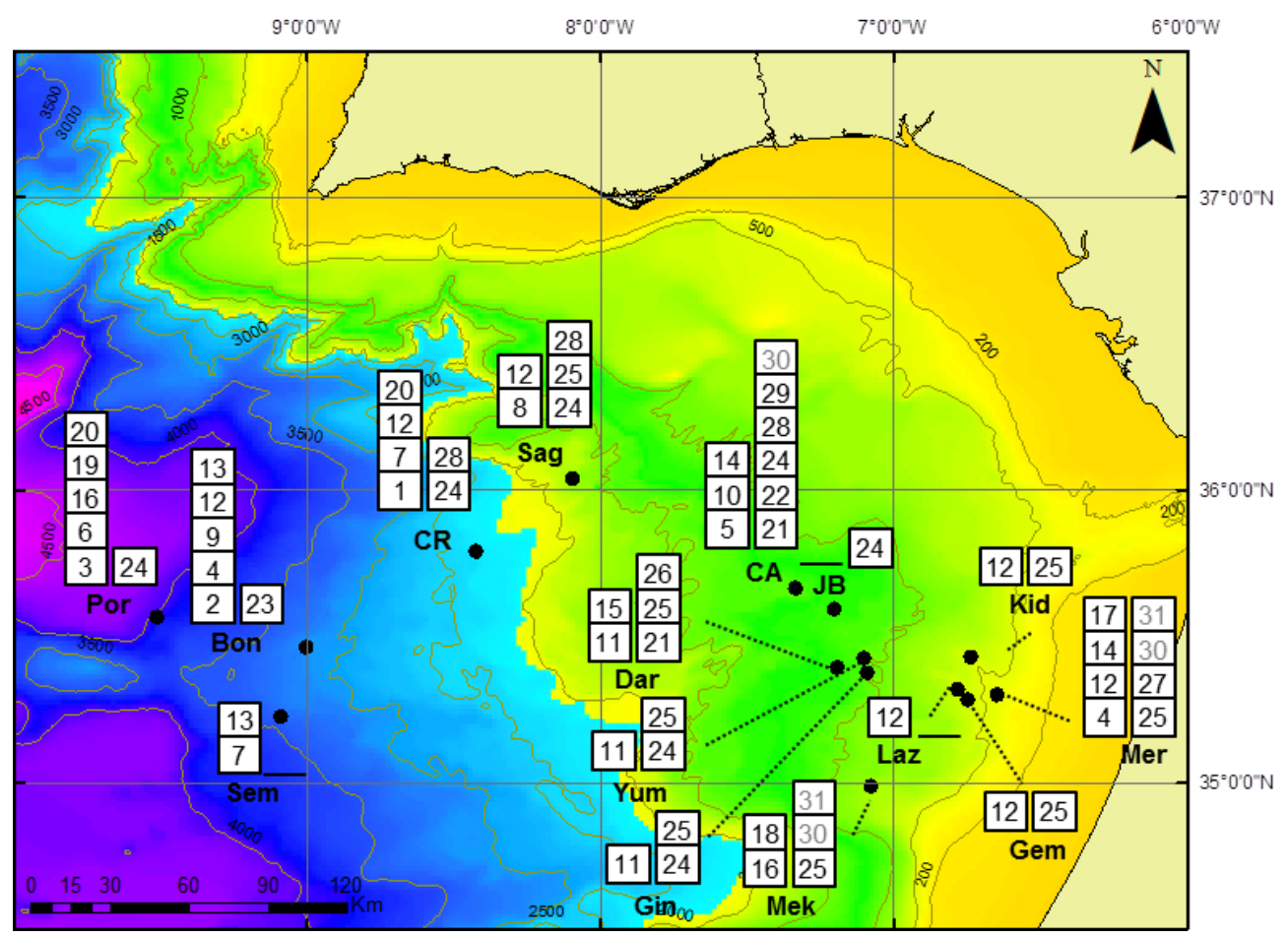

Fig. 1. Map of the Gulf of Cadiz showing the chemosymbiotic species distribution. Siboglinidae: (1) Bobmarleya gadensis; (2) Lamelisabella sp.; (3) Lamelisabella denticulata; (4) Polybrachia sp.1; (5) Polybrachia sp.2; (6) Polybrachia sp.3; (7) Polybrachia Va; (8) Polybrachia Vb; (9) Polybrachia Vc; (10) Siboglinum cf. poseidoni; (11) Siboglinum Ia; (12) Siboglinum Ib; (13) Siboglinum Ic; (14) Siboglinum Id; (15) Siboglinum Ie; (16) Siboglinum If; (17) Siboglinum sp.1; (18) Siboglinum sp.2; (19) Spirobrachia tripeira; (20) Undetermined IIa. Bivalvia: (21) Isorropodon megadesmus; (22) Isorropodon perplexum; (23) Christineconcha regab; (24) Acharax gadirae; (25) Solemya (Petrasma) elarraichensis; (26) “Bathymodiolus" mauritanicus; (27) Lucinoma asapheus; (28) Thyasira vulcolutre; (29) Spinaxinus sentosus; (30) Axinulus croulinensis (mixotrophic species); (31) Thyasira granulosa (mixotrophic species).

bivalves) were frozen and kept at $-80^{\circ} \mathrm{C}$ until further processing for stable isotope analysis.

The samples were freeze-dried and homogenized with a mortar-and-pestle grinding tool, and subsamples were separated for $\delta^{13} \mathrm{C}, \delta^{15} \mathrm{~N}$ and $\delta^{34} \mathrm{~S}$ analyses. The ground subsample for carbon analysis was acidified with $\mathrm{HCl}(1 \mathrm{M})$ until no further bubbling occurred; it was re-suspended in distilled water, centrifuged and the supernatant was discarded, finally the subsample was dried at $60^{\circ} \mathrm{C}$ and reground. The ground subsample for sulphur analysis was re-suspended in distilled water, shaken for $5 \mathrm{~min}$, centrifuged and the supernatant was discarded; this procedure was repeated 3 times and finally the subsample was dried at $60^{\circ} \mathrm{C}$ and reground.

The samples were analyzed at the ISO-Analytical laboratory (United Kingdom) using the technique EA-IRMS (elemental analysis - isotope ratio mass spectrometry).

The isotope compositions are reported in delta notation relative to standard material according to the following equation:

$\delta^{x} E=\left[\left({ }^{x} E /{ }^{y} E\right)_{\text {sample }} /\left({ }^{x} E /{ }^{y} E\right)_{\text {standard }}-1\right] \times 100$,

where $E$ is the element analysed (C, $\mathrm{N}$ or S), $x$ is the molecular weight of the heavier isotope, and y the molecular weight of the lighter isotope $(x=13,15,34$ and $y=12,14$ and 32 for $\mathrm{C}, \mathrm{N}$ and $\mathrm{S}$, respectively). The standard materials to which the samples are compared are the marine limestone fossil, Pee Dee Belemnite (V-PBD), for carbon (Craig, 1953); atmospheric air for nitrogen (Mariotti, 1983); and triolite from the Canyon Diabolo iron meteorite (V-CTD) for sulphur (Krouse, 1980).

Isotopic signatures of methane and gas hydrates for some of the studied mud volcanoes are available from the literature (Stadnitskaia et al., 2006; Hensen et al., 2007; Nuzzo et al., 2009) and compiled in Table S1 (Supplement).

\section{Results}

\subsection{Species distribution}

Chemosymbiotic species were identified from 15 mud volcanoes (MVs) with 11 bivalve species (including two mixotrophic) occurring at $13 \mathrm{MVs}$ and 20 siboglinid species at 14 MVs (Table 1, Fig. 1 and Supplement Fig. S1). The majority of the samples collected from a total of $24 \mathrm{MVs}$ in the Gulf of Cadiz yielded fragmented or empty siboglinid tubes and bivalve shells but these were not considered herein. 
Table 1. Sampling details of specimens collected for stable isotope analysis. Different quantitative and non-quantitative samplers were used. Station code is composed by the cruise name and station number as used in PANGAEA database (www.pangaea.de)

\begin{tabular}{|c|c|c|c|c|}
\hline $\begin{array}{l}\text { MV } \\
\quad \text { Station code }\end{array}$ & $\begin{array}{l}\text { Depth } \\
\text { (m) }\end{array}$ & $\begin{array}{l}\text { Latitude } \\
(\mathrm{N})\end{array}$ & $\begin{array}{l}\text { Longitude } \\
\text { (W) }\end{array}$ & Specimens code \\
\hline \multicolumn{5}{|l|}{ Mercator } \\
\hline TTR15_AT569 & 358 & $35^{\circ} 17.92^{\prime}$ & $06^{\circ} 38.72^{\prime}$ & $25.1 \mathrm{Mr}, 27.1 \mathrm{Mr}$ \\
\hline \multicolumn{5}{|l|}{ Gemini } \\
\hline M2007_15 & 444 & $35^{\circ} 09.60^{\prime}$ & $06^{\circ} 49.47^{\prime}$ & $12.1 \mathrm{Ge}$ \\
\hline M2007_19 & 430 & $35^{\circ} 06.44^{\prime}$ & $06^{\circ} 59.92^{\prime}$ & $12.2 \mathrm{Ge}, 25.2 \mathrm{Ge}, 25.3 \mathrm{Ge}$ \\
\hline \multicolumn{5}{|l|}{ Kidd } \\
\hline TT-R14_AT528 & 489 & $35^{\circ} 25.30^{\prime}$ & $06^{\circ} 43.97^{\prime}$ & $25.4 \mathrm{~K}$ \\
\hline \multicolumn{5}{|l|}{ Lazarillo de Tornes } \\
\hline M2006_38A & 494 & $35^{\circ} 19.09^{\prime}$ & $06^{\circ} 46.40^{\prime}$ & 12.3LT \\
\hline \multicolumn{5}{|l|}{ Meknès } \\
\hline TTR15_AT586 & 701 & $34^{\circ} 59.15^{\prime}$ & $07^{\circ} 04.38^{\prime}$ & $16.1 \mathrm{Mk}, 25.5 \mathrm{Mk}, 25.6 \mathrm{Mk}$ \\
\hline \multicolumn{5}{|l|}{ Yuma } \\
\hline TTR14_AT524 & 960 & $35^{\circ} 24.97^{\prime}$ & $07^{\circ} 05.46^{\prime}$ & $24.1 \mathrm{Y}$ \\
\hline TTR16_AT604 & 1030 & $35^{\circ} 25.82^{\prime}$ & $07^{\circ} 06.33^{\prime}$ & $24.2 \mathrm{Y}, 25.7 \mathrm{Y}$ \\
\hline TTR16_AT605 & 975 & $35^{\circ} 25.05^{\prime}$ & $07^{\circ} 05.45^{\prime}$ & 11.1Y, 24.3Y, 24.4Y \\
\hline \multicolumn{5}{|l|}{ Ginsburg } \\
\hline TTR16_AT607 & 983 & $35^{\circ} 22.68^{\prime}$ & $07^{\circ} 04.98^{\prime}$ & $24.5 \mathrm{Gi}$ \\
\hline \multicolumn{5}{|l|}{ Jesus Baraza } \\
\hline TTR12_AT391 & 1105 & $35^{\circ} 35.44^{\prime}$ & $07^{\circ} 12.26^{\prime}$ & $24.6 \mathrm{JB}$ \\
\hline \multicolumn{5}{|l|}{ Darwin } \\
\hline TTR16_AT608 & 1115 & $35^{\circ} 23.53^{\prime}$ & $07^{\circ} 11.47^{\prime}$ & $26.1 \mathrm{D}, 26.2 \mathrm{D}$ \\
\hline TTR17_AT664 & 1128 & $35^{\circ} 23.52^{\prime}$ & $07^{\circ} 11.48^{\prime}$ & $25.8 \mathrm{D}, 26.3 \mathrm{D}, 26.4 \mathrm{D}$ \\
\hline JC10_032 & 1109 & $35^{\circ} 23.52^{\prime}$ & $07^{\circ} 11.51^{\prime}$ & $25.9 \mathrm{D}, 26.5 \mathrm{D}, 26.6 \mathrm{D}$ \\
\hline \multicolumn{5}{|l|}{ Captain Arutyunov } \\
\hline TTR14_AT544 & 1330 & $35^{\circ} 39.71^{\prime}$ & $07^{\circ} 20.01^{\prime}$ & $10.1 \mathrm{CA}$ \\
\hline TTR14_AT546 & 1345 & $35^{\circ} 39.69^{\prime}$ & $07^{\circ} 20.05^{\prime}$ & $10.2 \mathrm{CA}$ \\
\hline MSM01/03_190\#1 & 1322 & $35^{\circ} 39.66^{\prime}$ & $07^{\circ} 19.97^{\prime}$ & 14.1CA \\
\hline MSM01/03_217\#1 & 1321 & $35^{\circ} 39.64^{\prime}$ & $07^{\circ} 20.05^{\prime}$ & $28.1 \mathrm{CA}$ \\
\hline MSM01/03_225 & 1320 & $35^{\circ} 39.71^{\prime}$ & $07^{\circ} 20.02^{\prime}$ & $28.2 \mathrm{CA}$ \\
\hline \multicolumn{5}{|l|}{ Sagres } \\
\hline TTR17_AT667 & 1562 & $36^{\circ} 02.20^{\prime}$ & $08^{\circ} 05.54^{\prime}$ & $12.4 \mathrm{~S}, 24.7 \mathrm{~S}, 25.10 \mathrm{~S}, 28.3 \mathrm{~S}$ \\
\hline \multicolumn{5}{|l|}{ Carlos Ribeiro } \\
\hline TTR16_AT615 & 2200 & $35^{\circ} 47.24^{\prime}$ & $08^{\circ} 25.27^{\prime}$ & $28.4 \mathrm{CR}, 28.5 \mathrm{CR}$ \\
\hline JC10_057 & 2175 & $35^{\circ} 47.25^{\prime}$ & $08^{\circ} 25.32^{\prime}$ & $28.6 \mathrm{CR}$ \\
\hline MSM01/03_157 & 2200 & $35^{\circ} 47.27^{\prime}$ & $08^{\circ} 25.36^{\prime}$ & $28.7 \mathrm{CR}$ \\
\hline MSM01/03_169 & 2199 & $35^{\circ} 47.26^{\prime}$ & $08^{\circ} 25.36^{\prime}$ & $24.8 \mathrm{CR}, 28.8 \mathrm{CR}$ \\
\hline \multicolumn{5}{|l|}{ Bonjardim } \\
\hline TTR15_AT597 & 3061 & $35^{\circ} 27.56^{\prime}$ & $09^{\circ} 00.03^{\prime}$ & $4.1 \mathrm{~B}$ \\
\hline \multicolumn{5}{|l|}{ Porto } \\
\hline MSM01/03_145 & 3860 & $35^{\circ} 33.70^{\prime}$ & $09^{\circ} 30.44^{\prime}$ & $3.1 \mathrm{P}, 24.9 \mathrm{P}$ \\
\hline
\end{tabular}

The solemyid Solemya elairrachensis was the most widespread chemosymbiotic bivalve (Fig. 1 and Supplement Fig. S1) occurring at eight MVs in the shallower El Arraiche field (Mercator, Gemini, Kidd) and in the Carbonate Province (Meknès, Yuma, Ginsburg, Darwin and Sagres). Another solemyid Acharax gadirae was found in seven MVs at greater water depths in the Carbonate Province (Yuma, Ginsburg, Jesus Baraza) and Deep Field (Capt. Arutyunov, Sagres, Carlos Ribeiro and Porto), with both solemyid species co-occurring at three mud volcanoes. The thyasirids were represented by two chemosymbiotic species occurring in MVs of the Deep Field - Thyasira vulcolutre (Capt. Arutyunov, Sagres and Carlos Ribeiro) and Spinaxinus sentosus (Capt. Arutyunov) - and two mixotrophic species occurring mainly at shallower water depths: Axinulus croulinensis (Mercator, Meknès and Capt. Arutyunov) and Thyasira granulosa (Mercator and Meknès). The three vesicomyid species were always found at water depths greater than $1000 \mathrm{~m}$ : two small Isorropodon species, I. megadesmus (Capt. Arutyunov and Darwin MVs) and I. perplexum (Capt. Arutyunov), and 
the larger Christenoconcha regab (Bonjardim MV). Lucinids and mytilids were each represented by a single species in only one MV (Lucinoma asapheus at Mercator MV and "Bathymodiolus" mauritanicus at Darwin MV, respectively).

The unitentaculate Frenulata genus Siboglinum was found in 14 MVs. From the nine Siboglinum species, Siboglinum Ib has the widest distribution in the Gulf of Cadiz, being present in seven MVs from approximately 350 to $3060 \mathrm{~m}$ water depth (Fig. 1 and Supplement Fig. S1). Siboglinum Ia is present in three MVs and three other species are found in two different MVs. The four remaining Siboglinum species are only found in one MV. It is worth noting the presence of the methanotrophic species Siboglinum cf. poseidoni (Rodrigues et al., 2011b) in the Capt. Arutyunov MV.

With the exception of one species of the genus Polybrachia, multitentaculate species are only present in MVs below $1300 \mathrm{~m}$ water depth. Only three of the eleven species are found in more than one MV: Polybrachia sp.1 is found in Mercator and Bonjardim, Polybrachia Va in Carlos Ribeiro and Semenovich, and one species of an undetermined genus (Undetermined IIa) in Carlos Ribeiro and Porto MVs (Fig. 1). The species Lamelisabella denticulata and Spirobrachia tripeira form conspicuous clumps of dark long tubes that cover the crater of Porto MV. The tubes of Bobmarleya gadensis are less conspicuous and more regularly spaced but were also observed forming a continuous field in the crater of Carlos Ribeiro MV.

\subsection{Stable isotope signatures - interspecific variation}

Stable isotope values were obtained for five bivalve species and seven siboglinid species (Table 2; Figs. 2 and 3). Although analyses were carried out in the gill and foot tissues for some bivalve specimens, no coherent differences in the isotopic values of these two tissues were observed and therefore only the average results per specimen are presented. Chemosymbiotic bivalves presented $\delta^{13} \mathrm{C}$ average values between -54.8 and $-27.2 \%$; the most depleted $\delta^{13} \mathrm{C}$ values were measured in "Bathymodiolus" mauritanicus from Darwin MV and the least depleted for Acharax gadirae from Sagres MV. There was a clear segregation between the mytilids and the other families (Solemyidae, Lucinidae and Thyasiridae) that never showed $\delta^{13} \mathrm{C}$ values below $-36.8 \%$ o (Fig. 2, Table 2). Despite some overlap of individual values, the different species showed distinct average $\delta^{13} \mathrm{C}$ signatures (Figs. 2 and 3). The overall $\delta^{15} \mathrm{~N}$ range for the chemosymbiotic bivalves $(10.5 \%$ ) was lower than the $\delta^{13} \mathrm{C}$ range $\left(27.5 \%\right.$ ); mean $\delta^{15} \mathrm{~N}$ values varied between -1.2 and $7.0 \%$ with Solemya elarraichensis, Lucinoma asapheus and Thyasira vulcolutre showing less depleted values than "B." mauritanicus and A. gadirae (Fig. 2, Table 2). The $\delta^{34} \mathrm{~S}$ values were the most variable with an overall range of $45.3 \%$ o. "Bathymodiolus" mauritanicus presented lighter $\delta^{34} \mathrm{~S}$ signatures and a relatively narrow range (values between 11.5 and $17.7 \%$ ). Thyasirids and solemyids showed more depleted signatures and much wider $\delta^{34} \mathrm{~S}$ ranges, especially A. gadirae (between -25.7 and $11.9 \%$ ) (Fig. 3, Table 2).

The $\delta^{13} \mathrm{C}$ values for Siboglinidae worms varied between $-49.8 \%$ (Siboglinum Id from Capt. Arutyunov MV) and $-33.1 \%$ (Siboglinum Ib, Gemini MV). Values of $\delta^{13} \mathrm{C}$ lower than $-40 \%$ were found for Siboglinum cf. poseidoni and Siboglinum Id, both in the Capt. Arutyunov MV, and for Lamelisabella denticulata from Porto MV (Figs. 2 and 3, Table 2). Except for Siboglinum Ib specimens from the shallow Gemini and Lazarillo de Tormes MVs that had values ranging from 8.2 to $12.2 \%$, the majority of the species showed $\delta^{15} \mathrm{~N}$ values below $6 \%$. Similarly, these two Siboglinum $\mathrm{Ib}$ samples also presented relatively high values of $\delta^{34} \mathrm{~S}$ ( 6.5 and $5.7 \%$ ). The lowest value of $\delta^{34} \mathrm{~S}(-16.8 \%$ ) was obtained for Siboglinum If from Meknès MV (Fig. 3, Table 2).

Overall, the set of different bivalve and tubeworm species in each MV show segregated trophic ranges; there is almost no overlap in $\delta^{13} \mathrm{C}$ values of co-occurring species and the cases of overlap in $\delta^{34} \mathrm{~S}$ ranges usually involve one tubeworm and one bivalve species (Fig. 3). Also, trophic diversity is lower at the shallower MVs than at the deeper ones where there is a higher number of chemosymbiotic species spanning a wider range of trophic signatures (Fig. 3).

\subsection{Intra-specific variation within and between study sites}

The mean $\delta^{13} \mathrm{C}$ values for Acharax gadirae specimens collected from six different mud volcanoes ranged from -27.2 to $-34.7 \%$ (Table 2 ), with a clear separation of values from specimens collected above ( -27.2 to $-29.3 \%$ in Ginsburg, Yuma, Jesus Baraza and Sagres MVs) and below $2000 \mathrm{~m}$ water depths $(-31.6$ to $-34.7 \%$ in Carlos Ribeiro and Porto MVs). Within the same site, variability was much smaller (1.3\%o in four specimens from Yuma MV). Solemya elarraichensis presented small intraspecific variation between sites $(2.0 \%)$ and negligible variation within the same site $\left(0.2\right.$ to $0.6 \%$ ). The $\delta^{13} \mathrm{C}$ signatures for the thyasirid Thyasira vulcolutre varied by $2.7 \%$, between specimens from Sagres and Carlos Ribeiro MVs, but most of the variation was observed among specimens from Carlos Ribeiro (range of 2.4\%o). "Bathymodiolus" mauritanicus showed the greatest variability within the same site (7.1\%o in Darwin MV).

The intraspecific range of mean $\delta^{15} \mathrm{~N}$ values in different sites varied from $3.0 \%$ (T. vulcolutre) to $6.1 \%$ (A. gadirae). Within the same site $S$. elarraichensis showed ranges of 2, 0.5 and $0.4 \%$ in the Gemini, Meknès and Darwin MVs, respectively. The four specimens of A. gadirae collected in the Yuma MV showed the widest range of $\delta^{15} \mathrm{~N}$ values within the same species and site for all studied species $(3.8 \%$ ). The $\delta^{15} \mathrm{~N}$ ranges were $0.5 \%$ in Capt. Arutyunov MV and $2.4 \%$ 。 in Carlos Ribeiro MV for T. vulcolutre and 3.0\%o in Darwin MV for "B." mauritanicus. 
Table 2. Stable isotope values of $\delta^{13} \mathrm{C}, \delta^{15} \mathrm{~N}$ and $\delta^{34} \mathrm{~S}$ (mean, standard error - SE and number of samples $-n$ ) for the different specimens studied here. Specimen codes according to Table $1 .{ }^{*}$ indicates that several specimens were pooled together

\begin{tabular}{|c|c|c|c|c|c|c|c|c|c|c|}
\hline \multirow[t]{2}{*}{ Specimens code } & \multirow[t]{2}{*}{ Species name } & \multicolumn{3}{|c|}{$\delta^{13} \mathrm{C}$} & \multicolumn{3}{|c|}{$\delta^{15} \mathrm{~N}$} & \multicolumn{3}{|c|}{$\delta^{34} \mathrm{~S}$} \\
\hline & & Mean & SE & $n$ & Mean & SE & $n$ & Mean & SE & $n$ \\
\hline & Siboglinidae - Frenulata & & & & & & & & & \\
\hline $3.1 \mathrm{P}$ & Lamelisabella denticulata* & -43.7 & & 1 & -0.6 & & 1 & -7.7 & & 1 \\
\hline $4.1 \mathrm{~B}$ & Polybrachia sp. $1^{*}$ & -36.9 & & 1 & -1.1 & & 1 & 2.5 & & 1 \\
\hline $10.1 \mathrm{CA}$ & Siboglinum cf. poseidoni* & -41.0 & & 1 & 2.7 & & 1 & 3.6 & & 1 \\
\hline $10.2 \mathrm{CA}$ & Siboglinum cf. poseidoni* & -44.5 & & 1 & 3.6 & & 1 & -8.2 & & 1 \\
\hline $11.1 \mathrm{Y}$ & Siboglinum $\mathrm{Ia}^{*}$ & -38.2 & & 1 & 3.0 & & 1 & 1.1 & & 1 \\
\hline $12.1 \mathrm{Ge}$ & Siboglinum $\mathrm{Ib}^{*}$ & -34.6 & & 1 & 8.7 & & 1 & 6.5 & & 1 \\
\hline $12.2 \mathrm{Ge}$ & Siboglinum $\mathrm{Ib}^{*}$ & -33.1 & & 1 & 12.2 & & 1 & & & \\
\hline $12.3 \mathrm{LT}$ & Siboglinum $\mathrm{Ib}^{*}$ & -35.9 & & 1 & 8.2 & & 1 & 5.7 & & 1 \\
\hline $12.4 \mathrm{~S}$ & Siboglinum $\mathrm{Ib}^{*}$ & -33.0 & & 1 & 0.2 & & 1 & -8.4 & & 1 \\
\hline $16.1 \mathrm{Mk}$ & Siboglinum If* $^{*}$ & -38.7 & & 1 & -1.3 & & 1 & -16.8 & & 1 \\
\hline $14.1 \mathrm{CA}$ & $\begin{array}{l}\text { Siboglinum } \mathrm{Id}^{*} \\
\text { Bivalvia }\end{array}$ & -49.8 & & 1 & 4.2 & & 1 & 6.0 & & 1 \\
\hline $24.1 \mathrm{Y}$ & Acharax gadirae* & -28.0 & 0.3 & 3 & 0.3 & 0.3 & 3 & -9.2 & 1.2 & 3 \\
\hline $24.2 \mathrm{Y}$ & Acharax gadirae & -29.3 & 0.6 & 3 & -2.3 & 0.3 & 3 & -12.3 & 1.4 & 3 \\
\hline $24.3 \mathrm{Y}$ & Acharax gadirae & -28.3 & 0.3 & 3 & 1.2 & 0.2 & 3 & -0.4 & 0.9 & 3 \\
\hline $24.4 \mathrm{Y}$ & Acharax gadirae & -29.2 & 0.1 & 3 & 1.5 & 0.4 & 3 & 1.9 & 0.7 & 3 \\
\hline $24.5 \mathrm{Gi}$ & Acharax gadirae & -28.8 & 0.6 & 3 & -3.4 & 0.3 & 3 & -5.4 & 1.0 & 3 \\
\hline $24.6 \mathrm{JB}$ & Acharax gadirae & -28.2 & 0.4 & 3 & -0.1 & 0.1 & 3 & -17.3 & 0.2 & 3 \\
\hline $24.7 \mathrm{~S}$ & Acharax gadirae & -27.2 & & 1 & -1.5 & & 1 & -5.3 & & 1 \\
\hline $24.8 \mathrm{CR}$ & Acharax gadirae & -34.7 & 0.3 & 3 & 2.7 & 0.2 & 3 & -25.7 & 1.7 & 3 \\
\hline $24.9 \mathrm{P}$ & Acharax gadirae & -31.6 & 0.3 & 3 & -1.4 & 0.2 & 3 & 11.9 & 1.9 & 3 \\
\hline $25.1 \mathrm{Mr}$ & Solemya elarraichensis* & -34.0 & 0.4 & 3 & 4.8 & 0.3 & 3 & -10.7 & 1.9 & 3 \\
\hline $25.2 \mathrm{Ge}$ & Solemya elarraichensis & -32.0 & 0.5 & 3 & 5.1 & 0.4 & 3 & -4.2 & 0.5 & 3 \\
\hline $25.3 \mathrm{Ge}$ & Solemya elarraichensis & -32.3 & 0.3 & 3 & 7.1 & 0.5 & 3 & -6.4 & 1.4 & 3 \\
\hline $25.4 \mathrm{~K}$ & Solemya elarraichensis* & -32.9 & 0.8 & 3 & 4.2 & 0.3 & 3 & -9.4 & 1.3 & 3 \\
\hline $25.5 \mathrm{Mk}$ & Solemya elarraichensis & -33.0 & 0.9 & 3 & 5.7 & 0.2 & 3 & -21.8 & 4.0 & 3 \\
\hline $25.6 \mathrm{Mk}$ & Solemya elarraichensis & -32.4 & 0.4 & 3 & 5.2 & 0.2 & 3 & -11.2 & 2.0 & 3 \\
\hline $25.7 \mathrm{Y}$ & Solemya elarraichensis & -33.5 & 1.1 & 3 & 2.0 & 0.4 & 3 & & & 1 \\
\hline $25.8 \mathrm{D}$ & Solemya elarraichensis & -32.7 & & 1 & 4.3 & & 1 & -0.8 & & \\
\hline 25.9D & Solemya elarraichensis & -33.2 & 0.2 & 3 & 3.9 & 0.2 & 3 & 2.2 & 1.0 & 3 \\
\hline $25.10 \mathrm{~S}$ & Solemya elarraichensis & -33.2 & 0.7 & 3 & 4.4 & 0.2 & 3 & 4.3 & 0.3 & 3 \\
\hline 26.1D & "Bathymodiolus" mauritanicus & -54.3 & & 1 & -0.7 & & 1 & 17.2 & & 1 \\
\hline $26.2 \mathrm{D}$ & "Bathymodiolus" mauritanicus & -51.4 & 0.4 & 3 & -0.4 & 0.1 & & 16.6 & 0.0 & 3 \\
\hline $26.3 \mathrm{D}$ & "Bathymodiolus" mauritanicus & -54.8 & & 1 & 1.8 & & 1 & 11.5 & & 1 \\
\hline 26.4D & "Bathymodiolus" mauritanicus & -50.0 & 0.7 & 3 & 0.5 & 0.1 & 3 & 11.6 & 0.6 & 3 \\
\hline $26.5 \mathrm{D}$ & "Bathymodiolus" mauritanicus & -47.7 & & 1 & -0.5 & & 1 & 17.7 & & 1 \\
\hline $26.6 \mathrm{D}$ & "Bathymodiolus" mauritanicus & -49.5 & 2.1 & 3 & -1.2 & 0.3 & 3 & 17.7 & & 1 \\
\hline $27.1 \mathrm{Mr}$ & Lucinoma asapheus* & -29.8 & 0.4 & 3 & 4.4 & 0.3 & 3 & -16.0 & 2.5 & 3 \\
\hline $28.1 \mathrm{CA}$ & Thyasira vulcolutre* & -34.9 & 0.6 & 3 & 4.1 & 0.9 & 3 & -14.0 & 2.4 & 3 \\
\hline $28.2 \mathrm{CA}$ & Thyasira vulcolutre* & -34.9 & 0.0 & 3 & 3.6 & 1.3 & 3 & -0.6 & 0.6 & 3 \\
\hline $28.3 \mathrm{~S}$ & Thyasira vulcolutre & -34.1 & 0.2 & 3 & 2.1 & 0.7 & 3 & -8.4 & 0.5 & 3 \\
\hline $28.4 \mathrm{CR}$ & Thyasira vulcolutre & -36.8 & 0.4 & 3 & 2.6 & 1.4 & 3 & 1.0 & 0.5 & 3 \\
\hline $28.5 \mathrm{CR}$ & Thyasira vulcolutre & -34.6 & 1.8 & 3 & 2.7 & 2.2 & 3 & 2.2 & 0.0 & 3 \\
\hline $28.6 \mathrm{CR}$ & Thyasira vulcolutre & -35.4 & 1.0 & 3 & 4.8 & 0.9 & 3 & & & 1 \\
\hline 28.7CR & Thyasira vulcolutre & -34.4 & 0.3 & 3 & 3.4 & 0.7 & 3 & -27.6 & 1.7 & 3 \\
\hline $28.8 \mathrm{CR}$ & Thyasira vulcolutre & -35.3 & 0.4 & 3 & 5.1 & 0.8 & 3 & -21.9 & & 1 \\
\hline
\end{tabular}

Isotopic signatures of $\delta^{34} \mathrm{~S}$ measured in A. gadirae showed a wide range $(37.6 \%$ ) with high variability within the same site (14.2\%o in Yuma MV) and between different sites (more than $20 \%$ ). In S. elarraichensis the $\delta^{34}$ S overall range was lower: $26.1 \%$ as well as within the same volcano $(2.2,10.6$ and $3.0 \%$ in Gemini, Meknès and Darwin MVs, respectively). Thyasira vulcolutre presented $\delta^{34} \mathrm{~S}$ ranges of $13.4 \%$ in Capt. Arutyunov MV and 29.8\%o in Carlos Ribeiro MV 

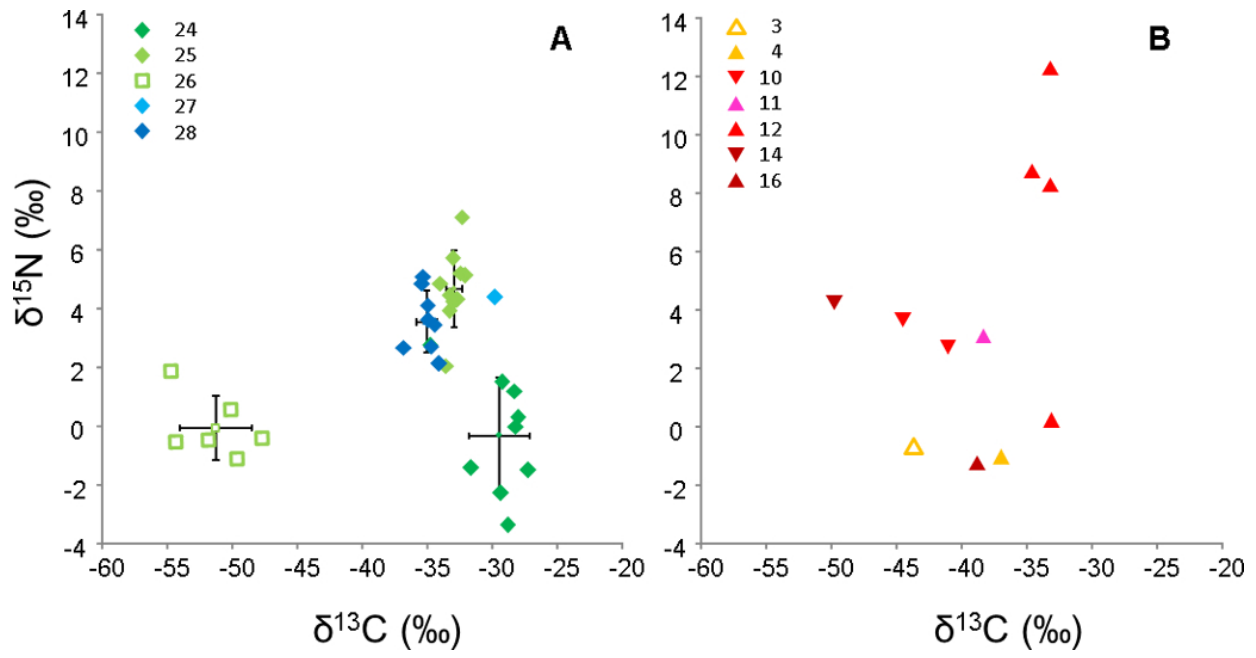

Fig. 2. Mean values (from Table 2) of $\delta^{13} \mathrm{C}$ vs. $\delta^{15} \mathrm{~N}$ for Bivalvia (A) and Frenulata (B) from the Gulf of Cadiz. Global mean values of species and respective standard error are also represented in (A). Species codes as defined in Fig. 1.

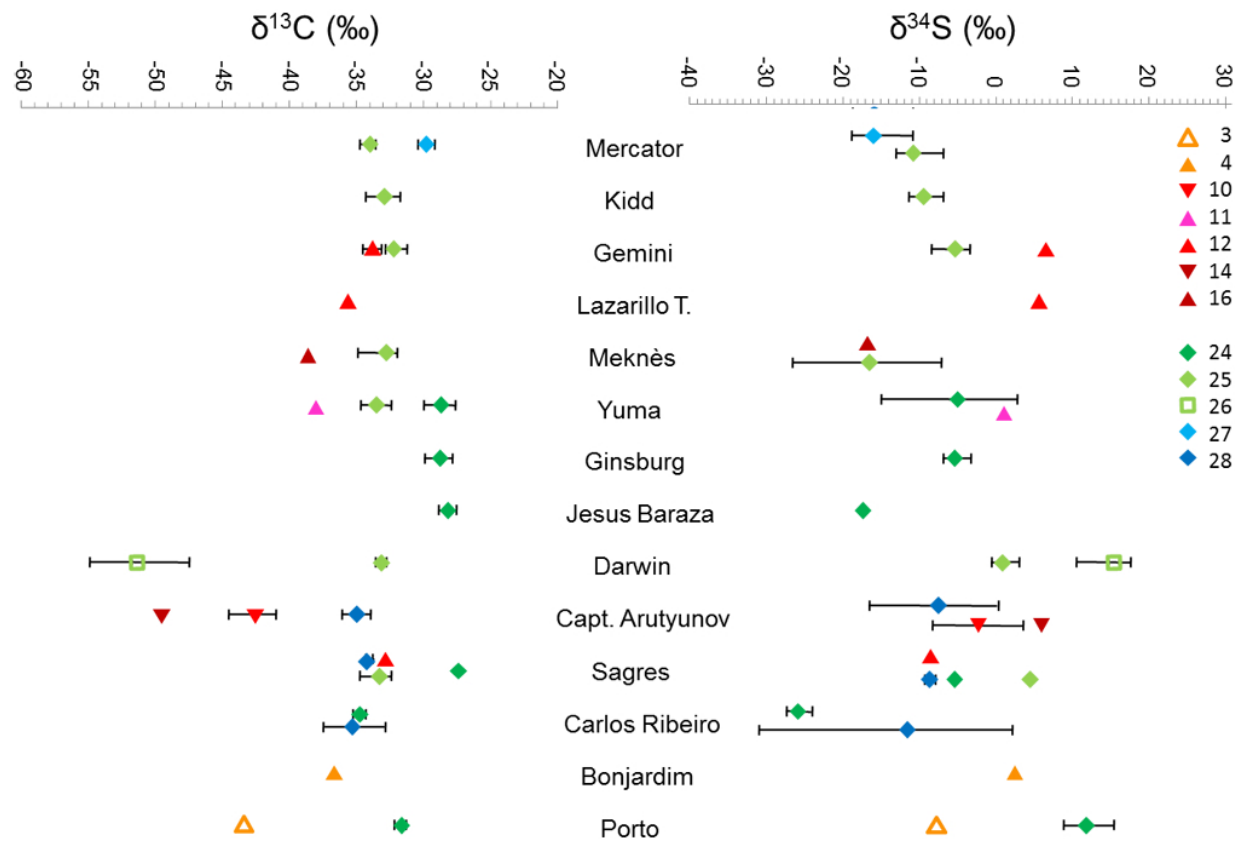

Fig. 3. Total ranges and average values (symbol) of $\delta^{13} \mathrm{C}$ and $\delta^{34} \mathrm{~S}$ of the different chemosymbiotic species co-occurring in each mud volcano. Species codes as defined in Fig. 1.

(comparable to the overall range for the species). The six specimens of "B." mauritanicus, all from Darwin MV, varied by $5.2 \%$.

Intra-specific variation of frenulate isotopic signatures could only be examined for the species Siboglinum Ib. The $\delta^{13} \mathrm{C}$ values varied from $-35.9 \%$ in the Lazarillo de Tormes MV to $-33 \%$ in the Sagres MV; $\delta^{15} \mathrm{~N}$ values varied from $0.2 \%$ (Sagres MV) to $12.2 \%$ (Gemini MV) and the $\delta^{34} \mathrm{~S}$ varied from -8.4 (Sagres MV) to $6.5 \%$ (Gemini MV).
Within Yuma MV, ranges of 1.5 and $3.5 \%$ were registered for $\delta^{13} \mathrm{C}$ and $\delta^{15} \mathrm{~N}$, respectively.

Overall, intraspecific $\delta^{13} \mathrm{C}$ ranges were narrower within the same MV than between different MVs while $\delta^{34}$ S ranges were sometimes higher within the same MV than between different MVs (Fig. 3). For each given species $\delta^{34}$ S ranges in different MVs were much more variable and usually wider than their $\delta^{13} \mathrm{C}$ ranges. 


\section{Discussion}

\subsection{Distribution and life styles}

Studies that combine form and function are essential to understand the ways in which chemosymbiotic species have evolved to exploit their environment and to interpret their current distribution. Because the association between a metazoan and its symbionts can be seen as an adaptation to bridge oxic-anoxic interfaces (Cavanaugh, 1994), the chemistry profile of the sediments is expected to play a role in determining which species are able to inhabit a particular site (Dando et al., 2008).

Solemyid, lucinid and thyasirid bivalves are sediment dwellers whose burrows span oxic-anoxic interfaces in the seafloor. Whereas solemyids form "U"- or "Y"-shaped burrows (Stewart and Cavanaugh, 2006), lucinids and thyasirids maintain an anterior inhalant connection to the surface (Taylor and Glover, 2000; Dufour, 2005) and produce long ramified burrows. In some thyasirids the length and number of burrows show a negative relationship with the concentration of hydrogen sulphide in the sediment (Dufour and Felbeck, 2003) and it has be proposed that lucinids and thyasirids are able to "mine" insoluble sulphides (Dando et al., 1994, 2004). Details of sulphur acquisition strategies are available for some lucinid and thyasirid species but both groups exhibit such a diversity of morphologies and live in such a wide variety of habitats that it is likely that they utilize a number of different behaviours and chemical pathways to acquire reduced sulphur from the environment (Taylor and Glover, 2000; Dufour, 2005). Regarding Vesicomyidae, most species live shallowly burrowed in sediment usually with the posterior half of the shell protruding (Krylova and Sahling, 2010); sulphide uptake is through the foot that protrudes into the sediment, while oxygen uptake is through the gill (Goffredi and Barry, 2002; Taylor and Glover, 2010). Finally, bathymodiolin mussels (family Mytilidae) are epibenthic and live attached by byssus threads to hard substrates, sometimes forming tight aggregates. Their reliance on chemosynthetic symbionts located in their gills implies that reduced compounds are needed in the surrounding fluid, as they do not have access to the anoxic sediment (Duperron, 2010). Bathymodiolin mussels occur in a broad range of environments, which may be attributed to their nutritional flexibility: some species are capable of hosting multiple symbioses, including the co-occurrence of sulphur- and methane-oxidizers, and can obtain additional nutrition from filter feeding (Fisher et al., 1993; Duperron et al., 2008).

Frenulata are generally described as tubeworms that extend over oxic-anoxic boundaries in the sediment, with the anterior end on the top layer of the sediment and the posterior tube and body buried in the sediment. However, this simplified description hides the variety of morphologies of different species that can show wide ranges of sizes (length and width), depth penetration in the sediment and tube thick- ness, all important features that may influence their ability to exploit different sources of nutrients.

In the Gulf of Cadiz, the methane-sulphate zone, where most microbial activity occurs, is usually more than $30 \mathrm{~cm}$ below the seafloor and often at $80 \mathrm{~cm}$ or more below the seafloor (Niemann et al., 2006; Hensen et al., 2007). An exception is Capt. Arutyunov MV where high methane concentrations were measured near the surface (Hensen et al., 2007). Burrowing bivalves and frenulates with long bodies were expected in mud volcanoes with wider redox boundaries, living in sediments where high sulphide concentrations are deep below the sediment interface. This holds true for frenulate species; for example the long frenulates Lamellisabella denticulata, Spirobrachia tripeira and Bobmarleya gadensis have only been found in Porto, Bonjardim and Carlos Ribeiro MVs, where high sulphide concentrations are deep $(>50 \mathrm{~cm})$ below the seafloor (Hensen et al., 2007; Nuzzo et al., 2008) and the presence of gas hydrate reservoirs is likely to ensure fluxes capable of sustaining larger body sizes (and consequently higher biomass). In Capt. Arutyunov MV geochemical gradients are steep but highly variable; the sediments are frequently disturbed by gas hydrate dissociation and sustain very high densities of smaller frenulates (Siboglinum spp.). At shallower MVs only the slim Siboglinum species and also Polybrachia sp.1 (at Mercator MV only) are found, but always in more modest densities (Cunha et al., 2013). The presence of small frenulates in MVs with a variety of geochemical settings suggests that smaller and shorter species may have more flexible requirements of reduced compounds, allowing them to exploit even lower concentrations that diffuse to the upper sediments.

The only epibenthic chemosymbiotic bivalve known in the Gulf of Cadiz, "Bathymodiolus" mauritanicus, was found in dense aggregations inhabiting the narrow fissures between the large carbonate slabs that pave the crater of Darwin MV; aggregations of small (young) individuals are rare, suggesting a strong intraspecific competition for the limited amount of favourable habitat where higher concentrations of reduced compounds reach the seafloor. In the Gulf of Cadiz, unlike many other cold seeps, chemosymbiotic bivalves are predominantly burrowing species that are found in a variety of MVs with very different geochemical settings. Solemyids are widespread but were always found at relatively low densities. Thyasirids are represented by several species; the juveniles and the smaller mixotrophic species may occur in relatively high densities and are often found closer to the sediment surface, while the larger species Thyasira vulcolutre is only found at the deeper (more active) MVs. The small vesicomyid Isorropodon megadesmus is one of the dominant species found in the near surface of gas-saturated sediments in Capt. Arutyunov MV (Cunha et al., 2013). Also for the vesicomyids, the larger species Cristineconcha regab was only found in one of the deeper MVs.

These distributions suggest that different species and/or ontogenic phases may adjust their position within the 
sediment according to their particular needs and to the intensity and variability in the supply of the chemical substrata. Little is known about the distributional patterns at the MV scale but up to five chemosymbiotic species were collected in a single boxcore sample (Cunha et al., 2013). The co-existence of such high numbers of bivalve and tubeworm species differing in size and shape at small spatial scales are a conspicuous manifestation of niche differentiation.

\subsection{Methanotrophy vs. thiotrophy}

Overall, the isotopic signatures of the chemosymbiotic species indicate the prevalence of a thiotrophic mode of nutrition for most species with the exception of $S$. cf. poseidoni and "B." mauritanicus. The presence of microbial symbionts was confirmed in the majority of the studied species with molecular characterization and fluorescent in situ hybridization (Rodrigues et al., 2010, 2011b, 2012, 2013; Rodrigues and Duperron, 2011). The isotopic signatures of the two bivalve tissues analysed (foot and gill) did not show coherent differences in any of the studied species, which as suggested in previous studies (Cary et al., 1989) is an indication of a high degree of carbon flow from the bacterial symbiont to the host.

Carbon isotopic values have been used to identify the source of methane as either biogenic $\left(\delta^{13} \mathrm{C} \leq-64 \%\right.$ when purely biogenic) or thermogenic $\left(-30 \geq \delta^{13} \mathrm{C} \geq-50 \%\right.$ o when purely thermogenic) methane (Schoell, 1980). The $\delta^{13} \mathrm{C}$ signature of the species harbouring methanotrophic symbionts, S. cf. poseidoni and Siboglinum Id from Capt. Arutyunov MV, and "B." mauritanicus from Darwin MV (Rodrigues et al., 2011b, 2013), are consistent with the inferred thermogenic origin of methane in the Capt. Arutyunov MV in particular and the Gulf of Cadiz in general (Nuzzo et al., 2008).

Average $\delta^{13} \mathrm{C}$ values for S.cf. poseidoni and Siboglinum Id were less depleted than values previously reported for $S$. poseidoni collected in Norwegian fjords which are known to harbour methane-oxidising bacteria (Schmaljohann and Flügel, 1987; Supplement Table S2). Nevertheless, the values reported here are compatible with methanotrophic nutrition, and molecular studies have already shown the occurrence of methane-oxidising bacteria in S.cf. poseidoni from the Capt. Arutyunov MV (Rodrigues et al., 2011b). The average of $\delta^{34} \mathrm{~S}$ value below $6 \%$ o found in S.cf. poseidoni was unexpected as it may indicate thiotrophy. A possible explanation for this value is a putative contamination of the sample by specimens belonging to other species. Because of their small size and morphological similarity, it is possible that co-occurring juveniles of Polybrachia sp. 2 may have been pooled together in the analysis, which complicates the interpretation of the results and may explain this apparent contradiction.

The highly depleted $\delta^{13} \mathrm{C}$ isotope signature of "B." mauritanicus, (species confirmed as part of the "childressi" group;
Génio et al., 2008) is in accordance with values previously reported for $B$. childressi (a known methanotrophic mussel; see Table S2). Molecular studies for "B." mauritanicus revealed the occurrence of a dual symbiosis with the presence of two phylotypes of methane-oxidising bacteria and a less abundant phylotype of a sulphur-oxidising bacterium (Rodrigues et al., 2013). Although thiotrophy is usually inferred from $\delta^{34} \mathrm{~S}$ values below 5\%o (Vetter and Fry 1998), the low abundance of sulphur-oxidising bacteria can explain the $\delta^{34} \mathrm{~S}$ values above $5 \%$ o found in our study. Isotopic values for mytilids are variable and dependent upon their nutrition, symbionts, ontogeny and local environmental conditions.

The isotope values of other bivalve and siboglinid species are consistent with the use of seawater $\mathrm{CO}_{2}$ fixed via sulphide oxidation and are in line with values reported for other species elsewhere. The $\delta^{13} \mathrm{C}$ values measured in L. asapheus are in the range of values reported for lucinids from other locations that are known to harbour thiotrophic symbionts (Table S2). The stable carbon isotope composition of $T$. vulcolutre is also similar to that registered for other Thyasira species (T. methanophila and T. sarsi; Table S2) and indicates that the autotrophic bacteria make a substantial contribution to the nutrition of the host. Chemoautotrophy is usually considered to be more important in the nutrition of thyasirids than of lucinids (Van Dover and Fry, 1989), which also seems to be the case in the Gulf of Cadiz, since T. vulcolutre have more depleted values of $\delta^{13} \mathrm{C}$ than $L$. asapheus. However, more depleted values may reflect local isotopic signatures of methane due to assimilation of pore water bicarbonate derived from microbial sulphate reduction coupled to methane oxidation (Scott et al., 2004; Becker et al., 2011). Methane isotopic signature (Table S1) is considerably less depleted at shallower MVs (higher thermal maturity of methane; Nuzzo et al., 2009) where L. asphaeus occurs than in the deeper MVs where T. vulcolutre is found.

\subsection{Resource partitioning}

The high diversity of chemosymbiotic species found in the Gulf of Cadiz may be explained by a combination of historical and contemporary factors (Cunha et al., 2013). The number of species coexisting in a single MV may be as high as nine (e.g. Capt. Arutyunov MV) and usually with no apparent zonation pattern, which suggests that there is resource partitioning. This may occur by means of differentiated life styles, differentiated metabolic pathways and strategies or by a combination of these. If chemical resource partitioning occurs, consistent differences in isotope values between species may be expected (Becker et al., 2011). Co-occurrence of phylogenetically close species is particularly interesting and in the Gulf of Cadiz it may be observed both for thyasirids and solemyids.

Overall, Solemya elarraichensis presented more depleted $\delta^{13} \mathrm{C}$ and more enriched $\delta^{15} \mathrm{~N}$ signatures than Acharax gadirae, which are probably consequences of metabolic and 
morphological differences between the two species. Symbionts of co-generics of both species are known to use different forms of the enzyme ribulose 1,5-bisphosphate carboxylase/oxygenase (RubisCO) for $\mathrm{CO}_{2}$ fixation. Whereas symbionts of Solemya species present RubisCO form I (Scott et al., 2004), symbionts of Acharax present the form II of the enzyme (Duperron et al., 2012), which has lower discrimination factors against ${ }^{13} \mathrm{CO}_{2}$. Previous studies have shown that the difference in discrimination against ${ }^{13} \mathrm{C}$ isotopes by the two forms of RubisCO can explain the disproportion in the ${ }^{13} \mathrm{C}$ values between two groups of chemosymbiotc invertebrates: the " $-30 \% \circ \delta^{13} \mathrm{C}$ group" with a form I RubisCO and the " $-11 \% \circ \delta^{13} \mathrm{C}$ group" expressing a form II (Robinson and Cavanaugh, 1995).

When compared with other taxa that also present form II RubisCO (e.g. vent vestimentiferans), the values found for $A$. gadirae are more depleted but are in accordance with the values found for the bivalves Calyptogena magnifica and Calyptogena pacifica (Southward et al., 1994; Fisher, 1995), which suggests that bivalves expressing RubisCO form II may have factors other than this enzyme structure and kinetics contributing to the carbon fractionation.

It is worth noting that within our samples of A. gadirae, specimens from deeper MVs presented more depleted $\delta^{13} \mathrm{C}$ values and in the same range of values found for $S$. elarraichensis. Oliver et al. (2011) ascribed Acharax specimens from Porto and Carlos Ribeiro mud volcanoes to the new species A. gadirae but because of the small size of the available specimens the same authors raised the possibility of the existence of a different species in these mud volcanoes, which could also explain the difference in the isotopic signatures.

When compared with previous data, the $\delta^{13} \mathrm{C}$ values of S. elarraichensis and of A. gadirae from the deeper mud volcanoes were similar to those found for other species of the same genera (Table S2). However, several differences were found in the $\delta^{15} \mathrm{~N}$ values between solemyid species, suggesting that they are using different chemical species of nitrogen, tapping different pools of nitrogen, or discriminating differently after acquisition of their nitrogen source. Furthermore, the $\delta^{15} \mathrm{~N}$ range may likely reflect a dilution of the very high ${ }^{15} \mathrm{~N}$ ammonium values occurring at the sediment water interface (Lee and Childressi, 1996; Carlier et al., 2010).

Nitrogen isotope values measured in various species of chemosymbiotic bivalves and frenulate tubeworms showed a wide range of values (Table S1), including one species with $\delta^{15} \mathrm{~N}$ values above $6 \%$ (value indicated by Levin and Michener (2002) as upper limit for the presence of chemoautotrophic symbionts). Similar relatively high values were found in Siboglinum Ib collected from three of the shallowest mud volcanoes and are probably related to the fact that these animals can exploit different sources of nitrogen. Siboglinum species are known to be able of take up and metabolize dissolved organic compounds in addition to the nutrition provided by their symbionts (Southward and Southward, 1981).
Furthermore, because of the shallower water depth they may have access to organic nitrogen derived from surface waters. On the contrary, low $\delta^{15} \mathrm{~N}$ values indicate that organic nitrogen is of local origin, presumably resulting from the activity of autotrophic bacteria (Levin, 2005; MacAvoy et al., 2008), and are possibly due to assimilation of isotopically light nitrate or ammonium by the symbionts or, in the case of the very negative values, possibly fixation of $\mathrm{N}_{2}$ (Fisher, 1995). As proposed by other authors (Carlier et al., 2010), we hypothesize that the inter-specific variations of $\delta^{15} \mathrm{~N}$ found in this study may result from species-specific types of symbionts characterized by different fractionation factors during the assimilation of dissolved inorganic nitrogen, and that in the particular case of frenulate tubeworms, different species may have different degrees of access and abilities to exploit dissolved organic compounds.

In general, there was considerably less intra-specific $\delta^{13} \mathrm{C}$ variation between specimens collected from the same volcano than from different MVs, which is plausibly explained by a higher variation in the composition of hydrocarbon pools at larger spatial scales (from one MV to another). These differences may be lower at shallow MVs as high thermal maturity of the gases is consistent with more limited differences in carbon isotopic composition (Nuzzo et al., 2009). However, there were relevant intra-specific differences in the isotopic signatures of chemosymbiotic species both within and between MVs. The observed intra-specific variation in the $\delta^{13} \mathrm{C}$ may result from the assimilation of DIC of diverse origins depending on the $\mathrm{MV}$, and in variable proportions, but also from the variable $\delta^{13} \mathrm{C}$ fractionation occurring during DIC fixation by endosymbionts, with the isotopic fractionation depending on the growth rate, and therefore on the size of each individual, as reported by other studies (Carlier et al., 2010).

Similar arguments can be used to explain the differences in the $\delta^{34} \mathrm{~S}$ signatures. There is little fractionation between sulphide and sulphate or organic sulphur as a result of sulphide oxidation by chemoautolithotrophic bacteria (reviewed in Canfield, 2001). Therefore, $\delta^{34} \mathrm{~S}$ values of animals with chemoautolithotrophic sulphur-oxidising symbionts reflect their reduced sulphur source (MacAvoy et al., 2005) and probably the relative abundance of reduced compounds available. $\delta^{34} \mathrm{~S}$ values were highly variable among individuals of the same species, either in different MVs or within the same $\mathrm{MV}$, reflecting high variability in the sulphide pool on a very small spatial scale. According to Becker et al. (2011), this pattern of high variability is consistent with the cycling of sulphate and sulphide between chemosymbiotic invertebrates and sediment microbial consortia. It is known that in the Gulf of Cadiz, the variations in environmental setting and AOM activity are reflected by very diverse microbial community compositions and that the three microbial consortia known to perform this reaction (ANME-1, -2, and -3) are active with different distribution patterns (Vanreusel et al., 2009). It is therefore probable that a diversity of sulphide sources 
is available locally for exploitation by the chemosymbiotic metazoans.

\section{Conclusions}

The number of chemosymbiotic species found in the Gulf of Cadiz is high when compared with other seep locations such as the mud volcanoes in the Eastern Mediterranean Sea and the Gulf of Guinea (Hilário et al., 2010; Oliver et al., 2011). Here we report for the first time on the distribution and life styles of these species and investigate resource partitioning at multiple spatial scales. Our results highlight the relevance of seep chemoautolithotrophic production in this area and provide a starting point for future trophic ecology studies. Long term observations on the biology of chemosymbiotic species coupled with geochemical measurements are still needed to better understand the interplay between environmental variability and symbiont dynamics.

In the Gulf of Cadiz thiotrophy is the dominant nutritional pathway, with methanotrophy and mixotrophy emerging as secondary strategies. We found a wide span of $\delta^{13} \mathrm{C}$ isotopic signatures that show well-segregated ranges between species and are relatively consistent within species as a result of species-specific metabolic pathways. Contrastingly, the $\delta^{34} \mathrm{~S}$ values are highly variable, both within and between species, and are likely the result of the great variability of the sulphide pool at local and regional scales. The diversity and the distribution of chemosymbiotic species in the Gulf of Cadiz reflect the environmental heterogeneity in terms of nutrient sources at local and regional scales. The mild seepage regimes at the shallower MVs favour the occurrence of mixotroph species that are capable of shifting opportunistically their feeding mode, while the deeper MVs with more intense although highly variable seep regimes sustain a higher trophic diversity (and biomass). The coexistence of an assortment of life styles is a conspicuous manifestation of niche differentiation and allows resource partitioning at multiple spatial scales. Overall, the variety of nutrient sources, metabolic pathways, feeding strategies and life styles translates into a unique taxonomical diversity with a direct impact on the seep assemblage and a relevant contribution to the regional biodiversity.

\section{Supplementary material related to this article is

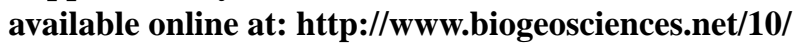 2569/2013/bg-10-2569-2013-supplement.pdf.}

Acknowledgements. Thanks are due to the chief-scientists for the invitation to participate in the TTR (Training through Research Programme, IOC-UNESCO), MSM01-03 (IFM-GEOMAR) and Microsystems 2006 and Moundforce 2007 (NIOZ) cruises. We are grateful to the two anonymous reviewers and the editor Jack Middelburg for their constructive comments, which helped to improve the quality of the manuscript. The research leading to these results was partially supported by the HERMES project, EC contract GOCE-CT-2005-511234, funded by the European Commission's Sixth Framework Programme under the priority "Sustainable Development, Global Change and Ecosystems" and the HERMIONE project (ENV/2008/226354) funded by the European Community's Seventh Framework Programme (FP7/2007-2013). CFR was supported by a post-doctoral fellowship (SFRH/BPD/64154/2009) from the Fundação para a Ciência e a Tecnologia (FCT, Portugal). AH was also supported by the FCT grants SFRH/BPD/22383/2005 and SFRH/BPD/ 760843/2011.

Edited by: J. Middelburg

\section{References}

Becker, E., Macko, S., Lee, R., and Fisher, C.: Stable isotopes provide new insights into vestimentiferan physiological ecology at Gulf of Mexico cold seeps, Naturwissenschaften, 98, 169-174, 2011.

Brooks, J. M., Kennicutt, M. C., Fisher, C. R., Macko, S. A., Cole, K., Childress, J. J., Bidigare, R. R., and Vetter, R. D.: Deep-sea hydrocarbon seep communities: evidence for energy and nutritional carbon sources, Science, 238, 1138-1142, 1987.

Canfield, D. E.: Biogeochemistry of Sulfur Isotopes, Rev. Mineral. Geochem., 43, 607-636, 2001.

Carlier, A., Ritt, B., Rodrigues, C. F., Sarrazin, J., Olu, K., Grall, J., and Clavier, J.: Heterogeneous energetic pathways and carbon sources on deep eastern Mediterranean cold seep communities, Mar. Biol., 157, 2545-2565, 2010.

Cary, C., Fry, B., Felbeck, H., and Vetter, R. D.: Multiple trophic resources for a chemoautotrophic community at a cold water brine seep at the base of the Florida Escarpment, Mar. Biol., 100, 411$418,1989$.

Cavanaugh, C. M.: Microbial Symbiosis: Patterns of Diversity in the Marine Environment, Am. Zool., 34, 79-89, 1994.

Cavanaugh, C. M., Wirsen, C. O., and Jannasch, H. W.: Evidence for Methylotrophic Symbionts in a Hydrothermal Vent Mussel (Bivalvia: Mytilidae) from the Mid-Atlantic Ridge, Appl. Environ. Microb., 58, 3799-3803, 1992.

Conway, N. M., Kennicutt Ii, M. C., and Van Dover, C. L.: Stable isotopes in the study of marine chemosynthetic-based ecosystems, in: Methods in ecology: Stable isotopes in ecology and environmental science, edited by: Lajtha, K. and Michener, R., Blackwell scientific, Great Britain, 158-186, 1994.

Craig, H., The geochemistry of the stable carbon isotopes. Geochim. Cosmochim. Ac., 3, 53-92, 1953.

Cunha, M. R., Rodrigues, C. F., Génio, L., Hilário, A., Ravara, A., and Pfannkuche, O.: Macrofaunal assemblages from mud volcanoes in the Gulf of Cadiz: abundance, biodiversity and diversity partitioning across spatial scales, Biogeosciences, 10, 25532568, doi:10.5194/bg-10-2553-2013, 2013.

Dando, P. R., Ridgway, S. A., and Spiro, B.: Sulphide mining by lucinid bivalve molluscs demonstrated by stable sulphur isotope measurements and experimental models, Mar. Ecol.-Prog. Ser., 107, 169-175, 1994.

Dando, P. R., Southward, A. J., and Southward, E. C.: Rates of sediment sulphide oxidation by the bivalve mollusc Thyasira sarsi, Mar. Ecol.-Prog. Ser., 280, 181-187, 2004. 
Dando, P. R., Southward, A. J., Southward, E. C., Lamont, P., and Harvey, R.: Interactions between sediment chemistry and frenulate pogonophores (Annelida) in the north-east Atlantic, DeepSea Res. I, 55, 966-996, 2008.

Dufour, S. C.: Gill Anatomy and the Evolution of Symbiosis in the Bivalve Family Thyasiridae, Biol. Bull., 208, 200-212, 2005.

Dufour, S. C. and Felbeck, H.: Sulphide mining by the superextensile foot of symbiotic thyasirid bivalves, Nature, 426, 65-67, 2003.

Duperron, S.: The Diversity of Deep-Sea Mussels and Their Bacterial Symbioses, in: The Vent and Seep Biota, edited by: Kiel, S., Topics in Geobiology, Springer, the Netherlands, 137-167, 2010.

Duperron, S., Halary, S., Lorion, J., Sibuet, M., and Gaill, F.: Unexpected co-occurrence of six bacterial symbionts in the gills of the cold seep mussel Idas sp. (Bivalvia: Mytilidae), Environ. Microb., 10, 433-445, 2008.

Duperron, S., Rodrigues, C. F., Léger, N., Szafranski, K., Decker, C., Olu, K., and Gaudron, S. M.: Diversity of symbioses between chemosynthetic bacteria and metazoans at the Guiness cold seep site (Gulf of Guinea, West Africa), MicrobiologyOpen, 1, 467480, 2012.

Fisher, C. R.: Chemoautotrophic and methanotrophic symbioses in marine invertebrates, Aquat. Sci., 2, 399-436, 1990.

Fisher, C. R.: Toward an appreciation of hydrothermnal-vent animals: Their environment, physiological ecology, and tissue stable isotope values, in: Seafloor Hydrothermal Systems: Physical, Chemical, Biological, and Geological Interactions, Geophys. Monogr. Ser., AGU, Washington, DC, 297-316, 1995.

Fisher, C. R., Brooks, J. M., Vodenichar, J. S., Zande, J. M., Childress, J. J., and Burke Jr., R. A.: The Co-occurrence of Methanotrophic and Chemoautotrophic Sulfur-Oxidizing Bacterial Symbionts in a Deep-sea Mussel, Mar. Ecol., 14, 277-289, 1993.

Génio, L., Johnson, S. B., Vrijenhoek, R. C., Cunha, M. R., Tyler, P. A., Kiel, S., and Little, C. T.: New record of "Bathymodiolus" mauritanicus Cosel 2002 from the Gulf of Cadiz (NE Atlantic) mud volcanoes, J. Shellfish Res., 27, 53-61, 2008.

Goffredi, S. K. and Barry, J. P.: Species-specific variation in sulfide physiology between closely related Vesicomyid clams, Mar. Ecol.-Prog. Ser., 225, 227-238, 2002.

Hensen, C., Nuzzo, M., Hornibrook, E., Pinheiro, L. M., Bock, B., Magalhaes, V. H., and Bruckmann, W.: Sources of mud volcano fluids in the Gulf of Cadiz - indicators for hydrothermal imprint, Geochim. Cosmochim. Ac., 2007.

Hilário, A. and Cunha, M. R.: On some frenulate species (Annelida: Polychaeta: Siboglinidae) from mud volcanoes in the Gulf of Cadiz (NE Atlantic), Sci. Mar., 72, 361-371, 2008.

Hilário, A., Johnson, S. B., Cunha, M. R., and Vrijenhoek, R. C.: High diversity of frenulates (Polychaeta: Siboglinidae) in the Gulf of Cadiz mud volcanoes: a DNA taxonomy analysis, DeepSea Res. I, 57, 143-150, 2010.

Hilário, A., Capa, M., Dahlgren, T. G., Halanych, K. M., Little, C. T. S., Thornhill, D. J., Verna, C., and Glover, A. G.: New Perspectives on the Ecology and Evolution of Siboglinid Tubeworms, Plos One, 6, e16309, doi:10.1371/journal.pone.0016309, 2011.

Kennicutt, M. C., Bueke, R. A., MacDonald, J. R., Brooks, J. M., Denoux, G. J., and Macko, S. A.: Stable isotope partioning in seep and vent organisms: chemical and ecological significance, in: Isotope Fractionations in Organic Matter: Biosynthetic and Diagenetic Processes., edited by: Macko, S. A. and Engel, M.
H., Chem. Geol. (Isot. Geosci. Sect.), 293-310, 1992.

Krouse, R.: Sulphur isotopes in our environment, in: Handbook of Environmental Isotope Geochemistry, 1, The Terrestrial Environment A, edited by: Fritz, P. and Fontes, J. C., 2nd Edn., Elsevier, Amsterdam, 435-472, 1980.

Krylova, E. M. and Sahling, H.: Vesicomyidae (Bivalvia): Current Taxonomy and Distribution, Plos One, 5, e9957, doi:10.1371/journal.pone.0009957, 2010.

Lee, R. W. and Childress, J. J.: Inorganic N assimilation and ammonium pools in a deep-sea mussel containing methanotrophic endosymbionts, Biol. Bull., 190, 373-384, doi:10.2307/1543030, 1996.

Levesque, C., Juniper, S. K., and Marcus, J.: Food resource partioning and competition among alvinelled polychaetes of Juan de Fuca Ridge hydrothermal vents, Mar. Ecol.-Prog. Ser., 246, 173-182, 2003.

Levin, L.: Ecology of cold seep sediments interactions of fauna with flow chemistry and microbes, Oceanogr. Mar. Biol., 43, 1-46, 2005.

Levin, L. A. and Michener, R. H.: Isotopic evidence for chemosynthesis-based nutrition of macrobenthos: The lightness of being at Pacific methane seeps, Limnol.Oceanogr., 47, 13361345, 2002.

MacAvoy, S. E., Carney, R. S., Fisher, C. R., and Macko, S. A.: Use of chemosynthetic biomass by large, mobile, benthic predators in the Gulf of Mexico, Mar. Ecol.-Prog. Ser., 225, 65-78, 2002.

MacAvoy, S. E., Fisher, C. R., Carney, R. S., and Macko, S. A.: Nutritional associations among fauna at hydrocarbon seep communities in the Gulf of Mexico, Mar. Ecol- Prog. Ser., 292, 51-60, 2005.

MacAvoy, S. E., Carney, R. S., Morgan, E., and Macko, S. A.: Stable isotope variation among the mussel Bathymodiolus childressi and associated heterotrophic fauna at four cold-seep communities in the Gulf of Mexico, J. Shellfish Res., 27, 147-151, 2008.

Mariotti, A.: Atmospheric nitrogen is a reliable standard for natural 15N abundance measurements, Nature, 303, 685-687, 1983.

Mazurenko, L. L., Soloviev, V. A., Belenkaya, I., Ivanov, M. K., and Pinheiro, L. M.: Mud volcano gas hydrate in the Gulf of Cadiz, Terra Nova, 14, 321-329, 2002.

Mazurenko, L. L., Soloviev, V. A., Gardner, J. M., and Ivanov, M. K.: Gas hydrates in the Ginsburg and Yuma mud volcano sediments (Moroccan Margin): results of chemical and isotopic studies of pore water, Mar. Geol., 195, 201-210, 2003.

Niemann, H., Duarte, J., Hensen, C., Omoregie, E., Magalhães, V. H., Elvert, M., L. M., P., Kopf, A., and Boetius, A.: Microbial methane turnover at mud volcanoes of the Gulf of Cadiz, Geochim. Cosmochim. Ac., 70, 5336-5355, 2006.

Nuzzo, M., Hornibrook, E. R. C., Hensen, C., Parkes, R. J., Cragg, B. A., Rinna, J., von Deimling, J. S., Sommer, S., Magalhaes, V. H., Reitz, A., Bruckmann, W., and Pinheiro, L. M.: Shallow Microbial Recycling of Deep-Sourced Carbon in Gulf of Cadiz Mud Volcanoes, Geomicrobiol. J., 25, 283-295, 2008.

Nuzzo, M., Hornibrook, E. R. C., Gill, F., Hensen, C., Pancost, R. D., Haeckel, M., Reitz, A., Scholz, F., Magalhaes, V. H., Bruckmann, W., and Pinheiro, L. M.: Origin of light volatile hydrocarbon gases in mud volcano fluids, Gulf of Cadiz - evidence for multiple sources and transport mechanisms in active sedimentary wedges, Chem. Geol., 266, 350-363, 2009. 
Oliver, P. G., Rodrigues, C. F., and Cunha, M. R.: Chemosymbiotic bivalves from the mud volcanoes of the Gulf of Cadiz, NE Atlantic, with descriptions of new species of Solemyidae, Lucinidae and Vesicomyidae, Zookeys, 113, 1-38, 2011.

Petersen, J. M., Zielinski, F. U., Pape, T., Seifert, R., Moraru, C., Amann, R., Hourdez, S., Girguis, P. R., Wankel, S. D., Barbe, V., Pelletier, E., Fink, D., Borowski, C., Bach, W., and Dubilier, N.: Hydrogen is an energy source for hydrothermal vent symbioses, Nature, 476, 176-180, 2011.

Pinheiro, L. M., Ivanov, M. K., Sautkin, A., Akmanov, G., Magalhães, V. H., Volkonskya, A., Monteiro, J. H., Somoza, L., Gardnaer, J., Hamouni, N., and Cunha, M. R.: Mud volcanism in the Gulf of Cadiz: results from the TTR-10 cruise, Mar. Geol., 195, 131-151, 2003.

Rau, G. H. and Hedges, J. I.: C-13 deplettion in a hydrothermal vent mussel - suggestion of a chemo-synthetic food source, Science, 203, 648-649, 1979.

Robinson, J. J. and Cavanaugh, C. M.: Expression of form I and form II Rubisco in chemoautotrophic symbioses: Implications for the interpretation of stable carbon isotope values., Limnol. Oceanogr., 46, 1496-1502, 1995.

Rodrigues, C. and Duperron, S.: Distinct symbiont lineages in three thyasirid species (Bivalvia: Thyasiridae) from the eastern Atlantic and Mediterranean Sea, Naturwissenschaften, 98, 281287, 2011

Rodrigues, C. F., Oliver, P. G., and Cunha, M. R.: Thyasiroidea (Mollusca: Bivalvia) from the mud volcanoes of the Gulf of Cadiz (NE Atlantic), Zootaxa, 1752, 41-56, 2008.

Rodrigues, C. F., Webster, G., Cunha, M. R., Duperron, S., and Weightman, A. J.: Chemosynthetic bacteria found in bivalve speci-es from mud volcanoes of the Gulf of Cadiz, FEMS Microbiol. Ecol., 73, 486-499, 2010.

Rodrigues, C. F., Paterson, G. L. J., Cabrinovic, A., and Cunha, M. R.: Deep-sea ophiuroids (Echinodermata: Ophiuroidea: Ophiurida) from the Gulf of Cadiz (NE Atlantic), Zootaxa, 2754, 126, 2011a.

Rodrigues, C., Hilário, A., Cunha, M., Weightman, A., and Webster, G.: Microbial diversity in Frenulata (Siboglinidae, Polychaeta) species from mud volcanoes in the Gulf of Cadiz (NE Atlantic), edited by: van Leeuw, A., J. Microbiol., 100, 83-98, 2011 b.

Rodrigues, C. F., Cunha, M. R., Olu, K., and Duperron, S.: The smaller vesicomyid bivalves in the genus Isorropodon (Bivalvia, Vesicomyidae, Pliocardiinae) also harbour chemoautotrophic symbionts, Symbiosis, 56, 129-137, 2012.

Rodrigues, C. F., Cunha, M. R., Génio, L., and Duperron, S.: A complex picture of associations between two host mussels and symbiotic bacteria in the northeast Atlantic, Naturwissenchaften, 100, 21-31, 2013.

Sassen, R., Joye, S., Sweet, S. T., DeFreitas, D. A., Milkov, A. V., and MacDonald, I. R.: Thermogenic gas hydrates and hydrocarbon gases in complex chemosynthetic communities, Gulf of Mexico continental slope, Org. Geochem., 30, 485-497, 1999.
Schmaljohann, R. and Flügel, H. J.: Methane-oxidizing bacteria in Pogonophora, Sarsia, 72, 91-98, 1987.

Schoell, M.: The hydrogen and carbon isotopic composition of methane from natural gases of various origins, Geochim. Cosmochim. Ac., 44, 649-661, 1980.

Scott, K. M., Schwedock, J., Schrag, D. P., and Cavanaugh, C. M.: Influence of form IA RubisCI and environmental dissolved inorganic carbin on the ${ }^{13} \mathrm{C}$ of the clam-chemoautotroph symbiosis Solemya velum, Environ. Microbiol., 6, 1210-1219, 2004.

Southward, A. J. and Southward, E. C.: Dissolved organic matter and the nutrition of the Pogonophora: a reassessment based on recent studies of their morphology and biology, Kieler Meeresf., $5,445-453,1981$.

Southward, A. J., Southward, E. C., Spiro, B., Rau, G. H., and Tunnicliffe, V.: C-13 C-12 of organisms from Juan de Fuca Ridge Hydrothermal vents - a guide to carbon and food sources, J. Mar. Biol. Assoc. UK, 74, 265-278, 1994.

Stadnitskaia, A., Ivanov, M. K., Blinova, V., Kreulen, R., and van Weering, T. C. E.: Molecular and carbon isotopic variability of hydrocarbon gases from mud volcanoes in the Gulf of Cadiz, NE Atlantic, Mar. Petrol. Geol., 23, 281-296, 2006.

Stewart, F. J. and Cavanaugh, C. M.: Bacterial endosymbioses in Solemya (Mollusca: Bivalvia) - Model systems for studies of symbiont - host adaptation, edite by: van Leeuw, A., J. Microbiol., 90, 343-360, 2006.

Taylor, J. D. and Glover, E. A.: Functional anatomy, chemosymbiosos and evolution of the Lucinidae, in: The Evolutionary biology of Bivalvia, edited by: Harper, E. M., Taylor, J. D., and Crame, J. A., Geological Society, London, 207-225, 2000.

Taylor, J. D. and Glover, E. A.: Chemosymbiotic Bivalves, in: The Vent and Seep Biota, edited by: Kiel, S., Topics in Geobiology, Springer Netherlands, 107-135, 2010.

Van Dover, C. L. and Fry, B.: Stable isotopic compositions of hydrothermal vent organisms, Mar. Biol., 102, 257-263, 1989.

Van Dover, C. L. and Fry, B.: Microorganims as food resources at deep-sea hydrothermal vents, Limnol. Oceanogr., 39, 51-57, 1994.

Van Rensbergen, P., Depreiter, D., Pannemans, B., Moerkerke, G., Van Rooij, D., Marsset, B., Akhmanov, G., Blinova, V., Ivanov, M., Rachidi, M., Magalhaes, V., L., P., Cunha, M., and Henriet, J. P.: The El Arraiche mud volcano field at the Moroccan Atlantic slope, Gulf of Cadiz, Mar. Geol., 219, 1-17, 2005.

Vanreusel, A., Andersen, A. C., Boetius, A., Connelly, D., Cunha, M. R., Decker, C., Hilário, A., Kormas, K. A., Maignien, L., Olu, K., Pachiadaki, M., Ritt, B., Rodrigues, C. F., Sarrazin, J., Tyler, P. A., Van Gaever, S., and Vanneste, H.: Biodiversity of cold seep ecosystems along the european margins, Oceanography, 110-127, 2009

Vetter, R. D. and Fry, B.: Sulfur contents and sulfur-isotope compositions of thiotrophic symbioses in bivalve molluscs and vestimentiferan worms, Mar. Biol., 132, 453-460, 1998. 